\section{AATS Online Award Applications Now Available at www.aats.org}

Deadline: July 1, 2010

Michael E. DeBakey Research Scholarship 2011-2013 provides an opportunity for research, training and experience for North American surgeons committed to pursuing an academic career in cardiothoracic surgery.

- Research program must be undertaken within the first three years after completion of an approved North American cardiothoracic residency.

- Applications for the scholarship must be submitted during the candidate's first two years in an academic position.

- The scholarship will begin July 1, 2011, and conclude on July 1, 2013.

- The Scholarship provides an annual stipend of $\$ 80,000$ per year paid to the host institution for direct salary support and related research expenses.

Deadline: July 1, 2010
Evarts A. Graham Memorial Traveling Fellowship, 2011-2012 grant supports training of international surgeons who have been regarded as having the potential for later international thoracic surgical leadership.

- Candidate must be a non-North American who plans a cardiothoracic surgery training program in a North American center and who has not had extensive (exceeding a total of six months in duration) clinical training in North America prior to making application.

- Candidate should have completed his/her formal training in general surgery and in thoracic and cardiovascular surgery, but should not have reached a senior position.

- The Fellowship provides a stipend of $\$ 75,000$ US, a major portion of which is intended for travel expenses incurred when visiting other medical centers.

Deadline: July 1, 2010

\section{The Western Thoracic Surgical Association}

\section{Applications for Membership}

Applications for membership in the Association must be received by the Membership Committee Chair no later than March 1, 2010 to be considered at the 2010 Annual Meeting. Applicants must be sponsored by three members of the Association who are not members of the Membership Committee. Application forms will be issued only to sponsoring members. Address correspondence to:

Chair, Membership Committee

The Western Thoracic Surgical Association

900 Cummings Center

Suite 221-U

Beverly, MA 01915

978-927-8330; fax: 978-524-8890

wtsa@prri.com

\section{WTSA 36th Annual Meeting}

June 23-26, 2010

Ojai Valley Inn

Ojai, California

Visit the WTSA Web site at www.westernthoracic.org and:

- View the scientific and social programs;

- Register before June 14, 2010, to avoid on site fee increases;

- Reserve your hotel room and read the Ojai Valley Inn's cancellation policy; and
- Get complete information on venue activities and local attractions.

\section{SCIENTIFIC HIGHLIGHTS}

Thursday, June 24, 2010

Presidential Address

J. Scott Millikan, Billings, Montana

Controversies in Thoracic Surgery

The Future of CT Practice Is an Employed Model

Friday, June 25, 2010

Simultaneous Breakfast Sessions*

Adult Cardiac: Blood Conservation in Adult Cardiac Surgery: How and Why

James Brevig, Everett, Washington

General Thoracic: Rescue Therapies for Acute Pulmonary Failure

Charles Hoopes, San Francisco, California

Congenital Heart Disease: Outcomes in Congenital Heart Surgery: What Do They Mean, What Should We Measure?

Karl F. Welke, Portland, Oregon

\section{Postgraduate Course}

The Emerging Science of Healthcare Delivery

Nicholas Wolter, Billings, Montana 
Saturday, June 26, 2010

C. Walton Lillehei Point/Counterpoint Session

Attending Surgeons Should Be Held to an 80-Hour

Workweek

Pro: Scott A. Shappell, Clemson, SC

Con: Irving L. Kron, Charlottesville, VA

\section{SOCIAL HIGHLIGHTS}

In addition to Wednesday's New Members Reception, Thursday's Samson Fun Run, Friday's Golf Tournament* and Tennis Tournament*, and Saturday's Family Luncheon and President's Banquet, don't miss the following Thursday events:

- The Ronald Reagan Presidential Library and Museum Tour*
- Taste of Ojai Street Festival Theme Dinner

*Separate Registration Required

\section{ACCREDITATION}

This activity has been planned and implemented in accordance with the Essential Areas and Policies of the Accreditation Council for Continuing Medical Education (ACCME) through the joint sponsorship of the American Association for Thoracic Surgery (AATS) and the WTSA. The AATS is accredited by the ACCME to provide continuing medical education for physicians.

This activity has been approved for 12.75 AMA PRA Category 1 Credit $(s)^{\mathrm{TM}}$. Physicians should only claim credit commensurate with the extent of their participation in the activity.

\section{The American Board of Thoracic Surgery}

\section{Notices}

The part I (written) examination was held on December 3. It is planned that this examination will be given at multiple sites throughout the United States using an electronic format. The closing date for registration is August 1 each year. Those wishing to be considered for examination must apply online at www.abts.org.

To be admissible for the Part II (oral) examination, a candidate must have successfully completed the Part I (written) examination.

A candidate applying for admission to the certifying examination must fulfill all the requirements of the Board in force at the time the application is received. Please address all communications to the American Board of Thoracic Surgery, 633 North St Clair Street, Suite 2320, Chicago, IL 60611 (telephone: 312-202-5900).

\section{Requirements for Maintenance of Certification}

Diplomates of the American Board of Thoracic Surgery (ABTS) who plan to participate in the Maintenance of Certification (MOC) process must hold an unrestricted medical license in the locale of their practice and privileges in a hospital accredited by the JCAHO (or other organization recognized by the ABTS). In addition, a valid ABTS certificate is an absolute requirement for entrance into the Maintenance of Certification process. If your certificate has expired, the only pathway for renewal of a certificate is to take and pass the Part I (written) and the Part II (oral) certifying examinations.
The names of individuals who have not maintained their certificate will no longer be published in the American Board of Medical Specialties Directories. Diplomates' names will be published upon successful completion of the Maintenance of Certification process.

The CME requirements are 30 Category I credits earned during each year prior to application. At least half of these CME hours need to be in the broad area of thoracic surgery. Category II credits are not allowed. Interested individuals should refer to the Booklet of Information for Maintenance of Certification for a complete description of acceptable CME credits. Diplomates will be expected to submit verification of CME earned.

Diplomates in the Maintenance of Certification process will need to provide a summary of their major cases performed during the year prior to application. The practice review should not exceed 100 cases.

Diplomates in the Maintenance of Certification process will be required to complete all sections of the SESATS self-assessment examination. It is not necessary for Diplomates to purchase SESATS individually, because it will be sent to them after their application has been approved.

Diplomates may apply for Maintenance of Certification in the year their certificate expires, or if they wish to do so, they may apply up to two years before it expires. However, the new certificate will be dated 10 years from the date of expiration of their original certificate or most recent recertification certificate. In other words, going through the Maintenance of Certification process early does not alter the 10-year validation. Diplomates certified prior to 1976 (the year that time-limited certificates were initiated) are 